Session 3461

\title{
What Would C.P. Snow Have To Say About Service-Learning in Engineering?
}

\author{
Edmund Tsang \\ Mechanical Engineering Department, University of South Alabama
}

\section{Introduction}

In his famous 1956 essay, "The Two Cultures" [1], C.P. Snow lamented at the state of contact and dialogue between scholars in the "traditional" culture of literature and the humanities, and the "scientific" culture of scientists, mathematicians and engineers. "The separation between the two cultures has been getting deeper under our eyes; there is now precious little communication between them, little but different kinds of incomprehension and dislike." Snow, who was a mathematician and a writer, stated that "[N]either culture knows the virtues of the other; often it seems they deliberately do not want to know." As a result, Snow thinks society and the public, as well as the scientists and humanists themselves, were deprived of the fruits of discussions and collaborations between "The Two Cultures." Snow stated: "On their side the scientists are losing a great deal...On the other side, how much does the traditional culture lose by the separation? I am inclined to think, even more."

This paper will speculate what C.P. Snow would say about service-learning in engineering. First, the paper will define service-learning and briefly survey servicelearning in engineering, including some preliminary results of student assessment. The paper will then present the arguments that C.P. Snow would approve of service-learning in engineering because service-learning offers opportunities for collaborations between "The Two Cultures," and because service-learning in engineering manifests the "moral" impulse behind the work of engineers and scientists described by Snow in "The Two Culture" article. Finally, the paper will surmise that service-learning in engineering is a form of "Public Engineering," analogous to the ideas of "Public Scholarship" [2] and "Public Science" [3] to meet the societal needs of the 21st Century.

\section{Service-Learning and Service-Learning in Engineering}

In a primer on service-learning in higher education [4], B. Jacoby gave this definition of service-learning: "Service-learning is a form of experiential education in which students engage in activities that address human and community needs together with structured opportunities intentionally designed to promote student learning and development. Reflection and reciprocity are key concepts of service-learning." Jacoby continues: 
"Service-Learning is based on the pedagogical principle that learning and development do not necessarily occur as a result of experience itself but as a result of a reflective component explicitly designed to foster learning and development. Reflection should include opportunities for participants to receive feedback from those persons being served, as well as from peers and program leaders." In Service-Learning, the goal of Reflection is "to promote learning about the larger social issues behind the needs to which their service is responding. This learning includes a deeper understanding of the historical, sociological, cultural, economic, and political contexts of the needs or issues being addressed." In Reciprocity, Jacoby explains that "[T]he needs of the community, as determined by its members, define what the service tasks will be. Service-learning avoids placing students into community settings based solely on desired student learning outcomes and providing services that do not meet actual needs or perpetuate a state of need rather than seeking and addressing the causes of need. Through reciprocity, students develop a greater sense of belonging and responsibility as members of a larger community. Community members being served learn how to take responsibility for their own needs and become empowered to develop mechanisms and relationships to address them."

Service-learning is well established in the humanities and social science (H/SS) fields and in disciplines where clinical experience is part of the education, but less so in engineering and the physical and life sciences. Campus Compact, a national group of about 700 colleges and universities, surveyed its member campuses in 1998 and found 11,800 service-learning courses were reported, and a 1998 study by University of California-Los Angeles found about one-third of all college students took a course that required them to do volunteer work [5]. Two large-scale studies -- one published in 1998 [6] and another in 1999 [7] -- found positive impacts of community service projects on student development and learning.

Though small in number, some engineering educators have integrated service-learning into their curricula and demonstrated positive impacts on some of the student attributes described in Criterion 3 of Engineering Criteria 2000. The Proceedings of the 2000 Annual Conference of the American Society for Engineering Education (ASEE) listed 12 papers on service-learning in engineering, and The American Association for Higher Education (AAHE) has published in Spring 2000 a monograph, Projects That Matter: Concepts and Models of Service-Learning in Engineering, which describes in detail several service-learning projects in engineering, including results of student assessment [8].

Among the notable service-learning engineering programs is the EPICS (Engineering Projects In Community Service) program of Purdue University [9], which has demonstrated positive effects of service-learning on students' "ability to work in a team," "communication skills," "awareness of the customer in an engineering projecct," "resourcefulness," and "understanding of the design process." EPICS has now been replicated at University of Notre Dame and Iowa State University. The ProCEED project of the Department of Mechanical Engineering, University of Michigan [10], has 
demonstrated that student participating in service-learning design projects, when compared to students working on traditional design projects, are "more likely to report that the course improved their ability to work with others to achieve shared goals, increased their willingness to help their community using their technical skills, and deepened their respect for the experiences and wisdom of people from backgrounds different from their own." John Duffy demonstrated how service-learning can be integrated into a variety of courses in the junior, senior and graduate level in the mechanical engineering curriculum [11]. A survey sent to 350 engineering deans by Duffy, et al [12] found "sixty-one engineering courses reported at a variety of levels (first year through graduate) encompassing a variety of topics including 'mainstream' discipline- specific courses, design courses, and two engineering community service courses." The authors stated that they "suspect that there may still be many unreported capstone design projects geared toward community service. Whether they have all the recommended aspects of service-learning such as community-defined needs, reciprocity, and reflection is unknown."

While community-based design projects can be found in the engineering curriculum, especially as part of capstone design, they are not service-learning projects (nor do their instructors identify these courses as such), because they focus primarily on engineering design and only incidentally involve community service and therefore do not have the reflection component of service-learning. Pritchard and Tsang observe that "even for those community-based design projects whose learning objectives match the objectives of service-learning, the student self-reflection component, without which the full benefits of service-learning are not realized, occurs more by happenstance than deliberately structured" [13]. They propose that these courses can reap the benefits of servicelearning by integrating a structured reflection component based on engineering ethics and social impacts of technology. They base their proposal on the fact that in the engineering codes of ethics of the American Society of Professional Engineers (ASPE) and the American Society for Civil Engineers (ASCE), "because there is no qualifier that engineers are to seek opportunities to be of service to the community 'in the performance of their professional duties,' it can be suggested that the obligations of engineers to the well-being of the public and their communities are not restricted to within their place of employment. Therefore, the NSPE and the ASCE provisions do provide a rationale for concluding that community service is an important feature of engineering ethics. Hence, service-learning can provide a more positive approach to engineering ethics by focusing learning on doing the work of an engineer responsibly and well, whether in the workplace or in community service."

\section{What C.P. Snow Would Say About Service-Learning In Engineering}

Service-learning requires engineering students to apply the knowledge and skills they learned in the classroom to address a human or societal need in their communities. Thus, the ideal behind the service-learning pedagogy manifests the same "moral" impulse behind the works of engineers and scientists that Snow described in his "The Two Cultures" essay. Snow elaborated: "But the greatest enrichment the scientific 
culture could give us is -- though it does not originate like that -- a moral one. Among scientists, deep-natured men know, as starkly as any men have known, that the individual human condition is tragic; for all its triumphs and joys, the essence of it is loneliness and the end death. But what they will not admit is that because the individual condition is tragic, therefore the social condition must be tragic, too. Because a man must die, that is no excuse for his dying before his time and after a servile life. The impulse behind the scientists drive them to limit the area of tragedy, to take nothing as tragic that can conceivably lie within men's will...It is that kind of moral health of the scientists which, in the last few years, the rest of us have needed most; and of which, because the two culture scarcely touch, we have been most deprived."

But future engineers will need more than technical knowledge and skills to assume the "moral" leadership in meeting the challenges of the 21 st Century, because solutions to many societal needs require the engineers to interact and communicate with people of diverse social, cultural and economic backgrounds, and to assume leadership with full understanding of the societal impacts of enginering. This would necessitate that the engineering education experience be broadened beyond technical knowledge and skills to include experiences that would produce more well-rounded graduates. Indeed, Criterion 3 of Engineering Criteria 2000 describes some of these attributes of future graduates of engineering programs [14]. Accordingly to a primer on service-learning in higher education [4], the goal of Reflection is "to promote learning about the larger social issues behind the needs to which their service is responding. This learning includes a deeper understanding of the historical, sociological, cultural, economic, and political contexts of the needs or issues being addressed." Thus, service-learning projects provide the context for engineering students to gain that experience to function in "multidisciplinary team" and " to communicate effectively," and through the reflection component of service learning to develop "an understanding of professional and ethical responsibility" and " the impacts of engineering solutions in a societal context."

Snow was "by education a scientist, by calling a writer" and he was able to bridge "The Two Culture." The author believes Snow would recognize the challange of the reflection component of service-learning in engineering offers an opportunity for collaboration between "The Two Cultures." Service-learning requires the engineering faculty and students consider the gray areas which inevitably arise when dealing with social issues and incorporate them into problem-solving. However, the traditional engineering curriculum emphasizes linear, black-and-white thinking with little room for personal introspection and reflection, and the engineering profession still lacks behind in diversity that is representative of the overall population. By training and temperment, most engineering faculty members feel uncomfortable leading reflection sessions. Thus, reflection in service-learning requires the engineering faculty to reach out to the humanities and social sciences faculty for collaboration, in order to fully realize the benefits of the service-learning pedagogy. Engineering faculty members have much to bring to this collaboration of "The Two Cultures" as Snow stated in his famous article: "Not only practically -- we are familiar with those arguments by now -- but also intellectually and morally." 


\section{Public Engineering}

"At no time in our history has the need been greater for connecting the work of the academy to the social and environmental challenges beyond the campus," Ernest L. Boyer wrote in 1990 [2], referring to decentralization of government that began in the 1980's, in which local communities, which often lack expertise and resources, are called upon to address societal needs in health care, safety, education, and the environment. As part of the civic awakening of America's higher education, Boyer proposes the idea of "scholarship of engagement" where academic institutions become "more vigorous partner[s] in the search for answers to our most pressing social, civic, economic, and moral problems." "In addition to research, the work of the academy must relate to the world beyond the campus," he wrote. In Boyer's view, because scholarship, and consequently the faculty reward system, has been narrowly defined in most universities, "the rich diversity and potential of American higher education cannot be fully realized." He proposed four areas of scholarship for university professors: discovery, integration, application, and teaching. Boyer called for "a renewed commitment to service" in institutions of higher learning because "afterall, many professors are drawn to the profession precisely because of their love for teaching or for service -- even for making the world a better place." For engineering educators, service-learning fits Boyer's expanded view of scholarship for university professors.

In response to Boyer's call for "scholarship of engagement," the Kettering Foundation proposes the idea of "Public Scholarship," where "scholars form partnership with citizens to produce knowledge that can be used to address a variety of public issues and problems." Peters, et al, in a paper published in the Kettering Foundation's Higher Education Exchange [3], propose the development of "Public Science," where science is seen as "public work that builds the commonwealth." "At its heart, it is a call for scientists to connect the work of science with the work of citizenship," the authors wrote. "The idea of a public science, like that of a public scholarship, is an expression of the nascent movement to link work and citizenship in academic institutions. Such a linking is surely necessary if these institutions are to effectively contribute to the development of a new "social contract' between science and society." "Public Science" calls on "scientists to enter into partnerships with citizens from other professions or sectors in work that closely linked knowledge creation with public problem solving and policy-making." This paper by Peter et al also includes examples of "Public Science" at University of Minnesota and Oregon State University, where Jane Lubchenko, a professor of zoology and a recent president of the American Association for the Advancement of Science (AAAS), called upon the scientific community in her 1997 AAAS presidential address to formulate a "new Social Contract" between science and society to respond to global changes.

"Public Engineering" is the new social contract between engineering and society, and Service-Learning in Engineering is the training ground for faculty and students to develop the knowledge and skills to implement "Public Engineering." In his essay in the 
AAHE monograph on Service-Learning in Engineering, R. Decker proposes that Service-Learning as a means for "Professional Activism," [15] where engineers will set aside a portion of their professional practice for service, similar to physicians and lawyers. Decker describes a plan for implementating Professional Activism by linking the alumni office and the office of community service of institutions of higher education, and the local chapters of professional engineering organizations.

\section{Conclusion}

In conclusion, the author believes C.P. Snow would approve of Service-Learning in Engineering because it manifests the "moral" impulse behind the work of engineering and because it challenges the engineering educators to bridge "The Two Cultures."

The Liberal Education Division of American Society for Engineering Education has set up an electronic discussion group to define "liberal education" for engineering students in the context of ABET's Engineering Criteria 2000, with the goal of producing a White Paper that will be presented at the 2001 Annual Conference [16]. This step was triggered by a presentation at the 2000 Annual Conference, in which the presenter aruged that EC 2000 presents an ideal opportunity to set standards for liberation education as a way of strengthening its role in engineering education.

Bibliography

1. Snow, C.P. "The Two Culture," in The New Statesman, LII, 413-414 (October 6, 1956).

2. Boyer, E.T. Scholarship Reconsidered: Priorities Of The Professoriate, Princeton University Press, Lawerenceville, NJ (1990).

3. Peters, S., Jordan, N. \& Lemme, G. "Toward A Public Science: Building a New Social Contract between Science and Society," Higher Education Exchange, Kettering Foundation, 34-47 (1999).

4. Jacoby, B. "Service-Learning in Today's Higher Education," in Service-Learning in Higher Education: Concepts and Practices, edited by B. Jacoby and Associates, JosseyBass, 1996, page 3-25.

5. Private communication with Campus Compact (November 2000).

6. Astin, A. W. \& Sax, L.J. "How Undergraduates Are Affected by Service Participation," Journal of College Student Development, 39 (3), 251-263 (1998).

7. Eyler, J. \& Giles, D. Where's the Learning in Service Learning?, Jossey-Bass Publisher, San Francisco, CA, (1999). 
8. Projects That Matter: Concepts and Models of Service-Learning in Engineering, ed. E. Tsang, American Association for Higher Education, Washington, DC (2000).

9. Oakes, W., Coyle, E., Jamieson, L., Watia, J., Gray, J., Wukasch, R.\& Foretek, R. "EPICS: Experiencing Engineering Design Through Community Service Projects," Proceedings of the Annual Conference of the American Society for Engineering Education, June 18-21, 2000, St. Louis, MO. Session 2625, CD-Rom (2000).

10. Stott, N., Schultz, W.,. Brei, D, Hoffman, D.M. \& Markus, G. "ProCEED: A Program for Civic Engagement in Engineering Design," Proceedings of the Annual Conference of the American Society for Engineering Education, June 18-21, 2000 St. Louis, MO. Session 2525, CD-Rom (2000).

11. Duffy, J. "Service-Learning in a Variety of Engineering Courses," in Projects That Matter: Concepts and Models of Service-Learning in Engineering, ed. E. Tsang, the American Association for Higher Education, Washington, DC, 75-98 (2000).

12. Duffy, J., Tsang, E. \& Lord, S. "Service-Learning in Engineering: What, Why, and How?" Proceedings of the Annual Conference of the American Society for Engineering Education, June 18-21, 2000, St. Louis, MO. Session 3630, CD-Rom (2000).

13. Pritchard M. \& Tsang, E. "Service-Learning: A Positive Approach to Teaching Engineering Ethics and Social Impact of Technology," Proceedings of the American Society for Engineering Education, June 18-21, St. Louis, MO. Session 3630, CD-Rom.

14. Engineering Criteria 2000, Accreditation Board for Engineering and Technology.

15. Decker, R. "Professional Activism: Reconnecting Community, Campus, and Alumni through Acts of Service," in Projects That Matter: Concepts and Models of ServiceLearning in Engineering, ed. E. Tsang, the American Association for Higher Education, Washington, DC, 53-57 (2000).

16. Communications from the Liberal Education Division of American Society for Engineering Education, November 2000.

\section{EDMUND TSANG}

Edmund Tsang is a associate professor of mechanical engineering at University of South Alabama. Dr. Tsang's current interests include enhancing the lower-division engineering curriculum, integrating service-learning into engineering education, and K-12 and public outreach. Dr. Tsang is the editor of a monograph on service-learning in engineering published in 2000 by the American Association for Higher Education (AAHE) titled, Projects That Matter: Concepts and Models for Service-Learning in Engineering. In 1999-2000, he was selected by the American Society for Engineering Education (ASEE) as a Visiting Scholar on service-learning in engineering. He received a Ph.D. in metallurgy from Iowa State University in 1977 and a B.S. degree in Mechanical Engineering from University of Nebraska in 1973. 